\title{
Human bone marrow mesenchymal progenitors: perspectives on an optimized in vitro manipulation
}

\author{
Eric Cordeiro-Spinetti ${ }^{1}$, Wallace de Mello ${ }^{1,2}$, Lucas Siqueira Trindade ${ }^{3}$, Dennis D. Taub ${ }^{4}$, \\ Russell S. Taichman ${ }^{5}$ and Alex Balduino ${ }^{1,6 *}$ \\ 1 LaBioTeC, Universidade Veiga de Almeida, Rio de Janeiro, Brazil \\ ${ }^{2}$ Laboratório de Pesquisas sobre o Timo, Instituto Oswaldo Cruz, Fiocruz, Rio de Janeiro, Brazil \\ ${ }^{3}$ Department of Biological Sciences, Tokyo Metropolitan University, Hachioji, Tokyo, Japan \\ ${ }^{4}$ Department of Vetarans Affairs, Hematology and Immunology Research, Washington DC Veterans Affairs Medical Center, Washington, DC, USA \\ ${ }^{5}$ School of Dentistry, Department of Periodontics and Oral Medicine, University of Michigan, Ann Arbor, MI, USA \\ ${ }^{6}$ Excellion Serviços Biomédicos, Petrópolis, Rio de Janeiro, Brazil
}

Edited by:

Mario Petrini, University of Pisa, Italy

Reviewed by:

Robert Paul Rhoads, Virginia

Polytechnic Institute and State

University, USA

Hong Zhang, Harvard Stem Cell

Institute, Harvard Medical School,

USA

\section{*Correspondence:}

Alex Balduino, Laboratório de

Biologia e Tecnologia Celular -

LaBioTeC, Universidade Veiga de

Almeida, Rua Ibituruna, 108, casa 3,

$2^{\circ}$ andar - Vila Universitária, Tijuca,

Rio de Janeiro, RJ 20271-901, Brazil

e-mail:balduino@uva.br
When it comes to regenerative medicine, mesenchymal stem cells (MSCs) are considered one of the most promising cell types for use in many cell therapies and bioengineering protocols. The International Society of Cellular Therapy recommended minimal criteria for defining multipotential MSC is based on adhesion and multipotency in vitro, and the presence or absence of select surface markers. Though these criteria help minimize discrepancies and allow some comparisons of data generated in different laboratories, the conditions in which cells are isolated and expanded are often not considered. Herein, we propose and recommend a few procedures to be followed to facilitate the establishment of quality control standards when working with mesenchymal progenitors isolation and expansion. Following these procedures, the classic Colony-Forming Unit-Fibroblast (CFU-f) assay is revisited and three major topics are considered to define conditions and to assist on protocol optimization and data interpretation. We envision that the creation of a guideline will help in the identification and isolation of long-term stem cells and short-term progenitors to better explore their regenerative potential for multiple therapeutic purposes.

Keywords: bone marrow, mesenchymal stem cell, colony, in vitro expansion, mutipotent progenitor

\section{INTRODUCTION}

To minimize discrepancies and inconsistencies, and allow comparison of data generated in different laboratories, members of the International Society of Cellular Therapy (ISCT) (Horwitz et al., 2005) have recommended minimal criteria for defining multipotential mesenchymal stem cells (MSCs). By ISCT criteria, MSCs must adhere and grow on a substrate in vitro and give rise to osteoblasts, chondrocytes, adipocytes, and hematopoiesissupporting reticular stroma when cultured under proper differentiation conditions. MSCs must also express CD73, CD90, and CD105, but not express hematopoietic cells and endothelial cells markers (Barry et al., 1999, 2001; Jones et al., 2002; Horwitz et al., 2005; Dominici et al., 2006; Sarugaser et al., 2009). Further investigation unveiled a few other surface markers, among which CD146 has been demonstrated to be consistently expressed by all MSCs and progenitors (Bianco et al., 1988; Shih, 1999; Dennis et al., 2002; Tuli et al., 2003; Zannettino et al., 2003; Sacchetti et al., 2007).

Growing evidence indicates an intimate relationship between MSCs and those cells identified as pericytes, since these two populations demonstrate similar behavior and potential in vitro and in vivo (Shi and Gronthos, 2003; Sacchetti et al., 2007; Taichman et al., 2010; Péault, 2012). Pericytes are perivascular cells which reside on the abluminal side of sinusoids and are known to express the proteoglycan NG2, alpha smooth muscle actin ( $\alpha \mathrm{SMA})$, and Platelet Derived Growth Factor Receptor
(PDGFR) (Andreeva et al., 1998; Crisan et al., 2008a, 2009; Maier et al., 2010). Similarities to pericytes led to the concept that all tissues in the body harbor their own population of mesenchymallike stem cells. Of note, it is important to stress that these cells are influenced by the niche they occupy in vivo, making them similar to each other, but with a few distinct characteristics and differentiation bias. Mesenchymal-like stem cells and progenitors have been isolated from several tissues, but adipose tissue and bone marrow are usually indicated as most promising sources of these cells by those working in the cell therapy and bioengineering fields (Da Silva Meirelles et al., 2006; Crisan et al., 2008b; Corselli et al., 2011). Yet to date, no specific or combination of markers can be used to distinguish multipotential MSCs from committed progenitors. A differentiation cascade, similar to the hematopoietic system, has not yet been assembled and confirmed.

Friedenstein and coworkers (Friedenstein et al., 1974a,b; Friedenstein, 1976; Owen and Friedenstein, 1988) were the first to describe the existence of a second category of progenitors residing in the marrow cavity, and named them stromal progenitor cells. His cues came with an in vivo assay, in which bone marrow cells were loaded into chambers and implanted subcutaneously in rats (Friedenstein et al., 1966, 1974b). After several weeks of implantation, bone-like mineralized nodules and cuboidal osteoblasts were observed inside the chambers in the new-formed tissue. The chamber's pores were too small and prevented cells from migrating into or out of the chambers, supporting the concept 
that the new bony tissue formed inside the chambers was exclusively generated from donor cells rather than recipient cells. Additional studies identified this activity belonging to the nonhematopoietic stromal fraction. In vitro, they showed that when bone marrow cells were placed into culture at low density, a few of them adhered, proliferated, and gave rise to colonies of fibroblast-like cells (CFU-f). These adherent fibroblast-like cells, but not the hematopoietic cells, when implanted in vivo, differentiated into bone tissue and bone marrow stroma, confirming that the bone marrow microenvironment is the niche for two distinct progenitors populations (Friedenstein et al., 1966, 1974a; Owen and Friedenstein, 1988). Cells were then named stromal stem cells. Later, further clonal manipulation and in vivo observations led different authors to propose different names, such as mesenchymal stem cells (Caplan, 1991, 2007) and skeletal stem cells (Bianco, 2011), to define almost the same cell population. However, it is important to stress that, even though these names have been used unrestrictedly as synonyms by several different authors, conceptually and originally, they indicate significant differences among the cells, mainly concerning their differentiation potential.

Although several research groups have described different strategies to isolate mesenchymal cells, the CFU-f assay has undergone almost no change since its original description by Friedenstein and coworkers (Friedenstein et al., 1970, 1974b). Higher proliferative rates are usually related to the stem cell and progenitor populations in most normal tissues. It is therefore assumed that each colony of fibroblast-like cells (CFU-f) originates from a single stem and/or progenitor cell (Friedenstein et al., 1966, 1974a,b; Latsinik and Epikhina, 1974; Friedenstein, 1976), and the number of colonies observed represents the number of mesenchymal progenitors as a fraction of the number of nucleated cells plated.

For researchers working with mesenchymal cells isolation and expansion, this is the most widely accepted assay used to quantify progenitors numbers. In the present perspective we addressed major topics we believe are most relevant regarding a few specific and distinct aspects of in vitro cell adhesion and growth. Even though CFU-f assay is very simple to perform, we proposed three different strategies based on progenitors in vitro clonogenic potential, which might be helpful to define standard conditions to optimize in vitro manipulation, and provide data linearity and reproducibility.

\section{NUMBER OF CELLS IN A COLONY}

In the late 1960's and early 1970's, Alexander Friedenstein and colleagues (Friedenstein et al., 1966, 1970) began their journey into the bone marrow cavity and defined the primary conditions to quantify a sub-population of, by that time, osteogenic progenitors among all bone marrow stromal cells (Friedenstein et al., 1966, 1982). In the original protocol, single cell suspensions of bone marrow cells are plated at low-density $\left(10^{4}-10^{5}\right.$ nucleated cells per $\mathrm{cm}^{2}$ ) and incubated in DMEM supplemented with fetal bovine serum (FBS). Seventy-two hours later, the non-adherent cells are washed out and the adherent fraction is incubated in fresh culture medium. Culture medium is renewed every 3-4 days over a ten-day culture. After a total of 13 days, the cells are fixed and further stained in crystal violet, and the colonies are counted (Satomura et al., 2000; Kuznetsov et al., 2009). It is assumed in this case that when bone marrow cells are plated in low-density cultures, the colonies will not reach each other's borders supporting that each colony is derived from a single progenitor. However, it is important to keep in mind that colonies are heterogeneous and, although each one is derived from a single progenitor, not all display a multilineage differentiation potential. Many are already committed to a specific lineage, following the hierarchical-like and controlled differentiation cascade (Muraglia et al., 2000; Sarugaser et al., 2009; Russell et al., 2010). Colonies also display different sizes and cell distribution within the cultures, which may correlate to cell differentiation stage (Figure 1). Additional studies have revealed that $\sim 30 \%$ of all BM mesenchymal progenitors colonies present trilineage potentialosteogenic, chondrogenic, and adipogenic - in vitro. Sacchetti and coworkers (Sacchetti et al., 2007) demonstrated that $~ 50 \%$ of the $\mathrm{CD} 146^{+}$clonal mesenchymal progenitors isolated from the bone marrow cultures give rise to compact bone, but not bone marrow, when implanted in vivo, indicating that half of the progenitors, upon isolation from an adult bone marrow, are already committed to the osteogenic lineage.

As for several tissues, cells are classified into three categories: (1) stem cells, (2) intermediate progenitors and (3) differentiated cells. Typically, differentiated cells possess low proliferation ability in vitro, while intermediate progenitors present high proliferative rates under stimulus. On the other hand, stem cells are quiescent cells in vivo, but in vitro, under the proper culture conditions, exit the quiescence stage and become highly proliferative (Stanley et al., 1971; Urabe et al., 1979; Nicola and Metcalf, 1986; Oh and Humphries, 2012; Bianco et al., 2013). When analyzed in this perspective, it is expected that several stromal cell populations adhere to the culture flask surface in the first three days of culture, namely differentiated reticular cells, committed progenitors and stem cells. Only progenitors and stem cells will proliferate to generate colonies. Regardless progenitors commitment, what features each group of cells must present to be identified as a colony? Based on the original protocol and refinements suggested by several laboratories (Wagner et al., 2009; Bianco et al., 2013), only colonies consisting of more than 50 cells should be classified as a colony (Kuznetsov et al., 2009). Colonies quantification can be performed under the microscope, but stained colonies with more than 50 cells are easily observed directly by the "naked eye." It must be acknowledged that growth-promoting activity will vary from FBS lot to lot, which may change CFU-f results. Thus, a quality control should be used to screen FBS lots to avoid suboptimal or "superoptimal" conditions, which may result in changes in colony formation and impact cell growth and differentiation (Mannello and Tonti, 2007).

It is clear that cell proliferation status changes accordingly as FBS is changed, which will considerably impact CFU-f results. Cell proliferation depends upon growth factors concentration and, regardless all the controls applied to serum fabrication, this varies largely from FBS lot to lot. Conversely, it is not clear how progenitors respond to serum variations. It must be determined if proliferation of progenitors in vitro follows a simultaneous or selective growth pattern, the latter being all 


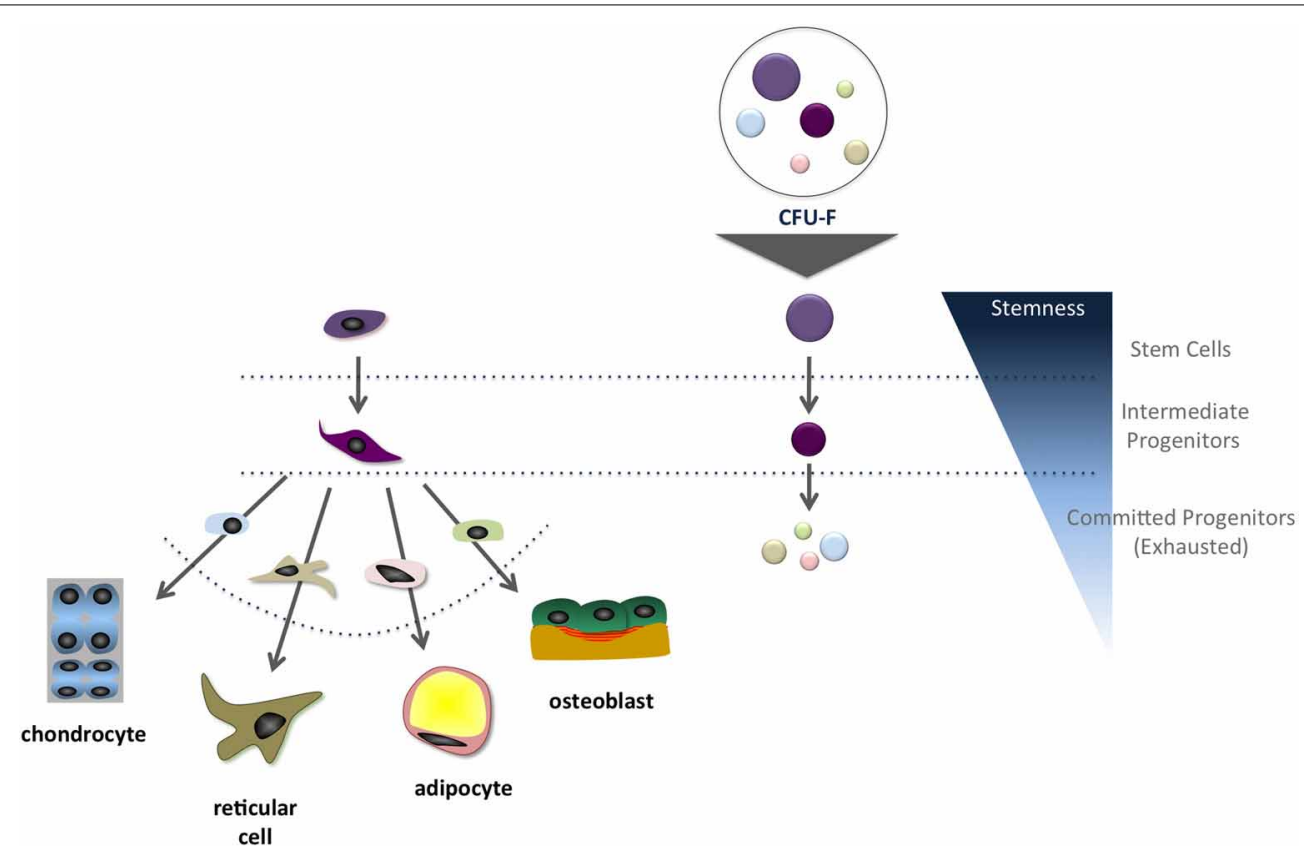

FIGURE 1 | Schematic representation of the suggested correlation between the mesenchymal stem cell differentiation cascade and colony size in vitro. It is frequently inferred that most primitive progenitors give rise to larger colonies compared to those originated from intermediate and committed progenitors.

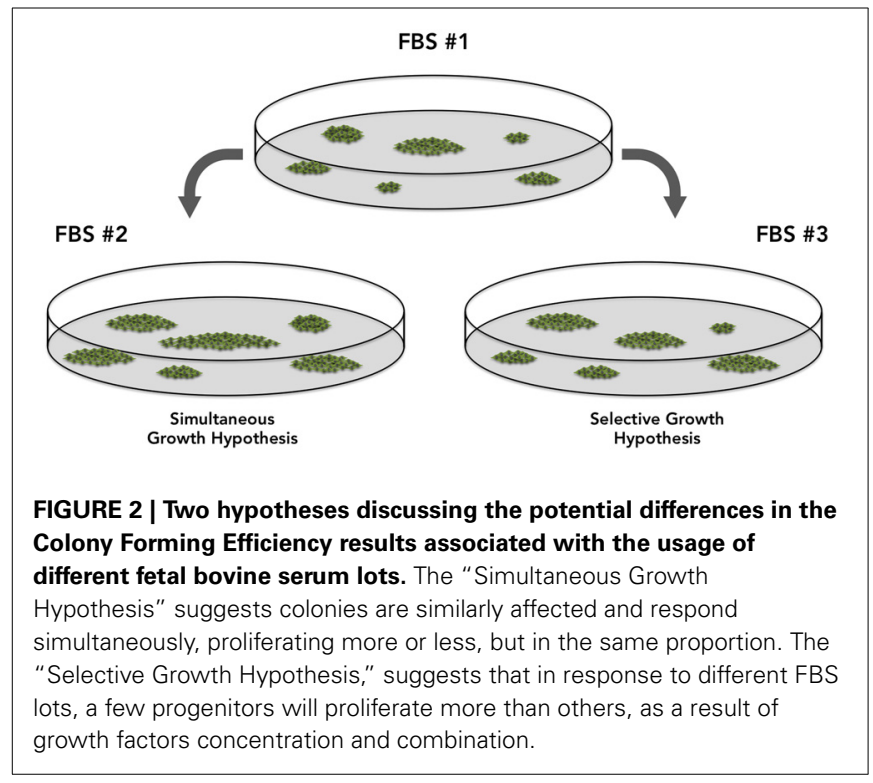

progenitors will respond differently when FBS lot is changed (Figure 2). It is expected that all progenitors in a plate respond similarly (Simultaneous Growth Hypothesis) and, as the FBS lot is changed, they all may proliferate more or less. It is unclear if this is what occurs in vitro. Different from the concept that all colonies will be bigger or smaller, the Selective Growth Hypothesis proposes that big colonies might get bigger and small clusters might even not reach the colony status.

At this point, one should know that colony size (the number of cells in a colony) will matter, but only under optimized conditions. To avoid discrepancies and ensure reproducibility, the ideal condition would be to run the CFE assay under chemically defined and controlled culture medium conditions, using recombinant growth factors instead of serum, but this can be cost prohibitive. Moreover, what combination of factors is necessary to expand mesenchymal progenitors in vitro remains to be defined. We propose, however, that colony number, colony size, and progenitors phenotype be tested every time serum change is necessary.

\section{DOES COLONY SIZE RELATE TO STEMNESS?}

Colony forming ability is not exclusive to the mesenchymal system (Queensberry et al., 1974; Dexter, 1979; Nicola and Metcalf, 1986). A similar in vitro assay has been widely used to quantify hematopoietic progenitor cells. In the past, this was the only quantification tool, but it was replaced by the development of more meticulous flow cytometric phenotyping methods, which is now mostly utilized to quantify and identify hematopoietic stem cells and progenitors, although the colony assay remains widely used. It must be clear, however, that cell transplantation into myeloablated animals is the only way to fully identify bona fide long-term hematopoietic stem cells (Morrison et al., 1995; Gazit et al., 2008).

Hematopoietic stem cells and progenitor colony forming ability is observed when cells are cultured in semi-solid culture medium, which maintains them in close proximity to each other, as they proliferate in the presence of specific growth factors (Queensberry et al., 1974; Dexter, 1979; Nicola and Metcalf, 1986). Unlike the CFU-f assay, which is used to quantify MSCs and committed progenitors indiscriminately, the colony forming assay can be used to quantify lymphoid, erythroid, myeloid, 
and multipotent progenitors separately depending on the combination of specific growth factors added to the culture system (Stanley et al., 1971; Dexter, 1979; Urabe et al., 1979; Nicola and Metcalf, 1986; Quesenberry et al., 1987). Hematopoietic progenitors grow at different culture rates and present distinct morphologies in vitro, allowing identification and quantification of different progenitors separately and quickly.

One major observation from the hematopoietic colonyforming assay is that committed progenitors start to proliferate early (day 1 of culture), and develop into distinct colonies in 5-10 days. On the other hand, most primitive progenitors can take a few days to exit the quiescent stage and will eventually form full colonies after 9-14 days in culture (Stanley et al., 1971; Dexter, 1979; Urabe et al., 1979; Nicola and Metcalf, 1986; Quesenberry et al., 1987). Although primitive progenitors take longer to form colonies, the colonies generated are typically $2-4$ times larger than those derived from committed progenitors. This in vitro behavior is in full accordance with in vivo observations, as hematopoietic stem cells are typically quiescent however, when properly stimulated, achieve higher proliferative rates compared to other progenitors (Carow et al., 1993; Ponchio et al., 1995; Hao et al., 1996; Petzer et al., 1996; Oh and Humphries, 2012). For these reasons it is often inferred that the larger the colony, the more primitive the progenitor it had been derived from.

A similar line of observation could be applied to the colonyforming unit fibroblast assay. In a 13-day culture, the committed progenitors will initiate proliferation faster in vitro giving rise to colonies, but these cells will rapidly undergo clonal exhaustion. Conversely, uncommitted progenitors will take longer to activate the proliferation cascade, and do not arrest during the culture period and thus result in larger colonies. Indeed, it is not unusual to correlate colony size with primitiveness of the cell of origin.

A question remains unanswered: "Is thirteen days sufficient for all multipotential stem cells to enter the cell cycle and become highly proliferative cells ex vivo?" Primitive stem cells are likely to remain deeply quiescent or proliferate very slowly in vivo. When placed in vitro, they may require longer to leave the quiescent stage but, once stimulated, their proliferative rate is likely to increase beyond that observed for intermediate progenitors. Many hypothesize that the most quiescent mesenchymal stem cells might take longer to start proliferation in vitro, which means that a few small/medium colonies may not be representative of exhausted committed progenitors, but rather indicate yet-toproliferate stem cells (Figure 3). This possibility challenges many assumptions derived from the CFU-f assay, and suggests that colony size may not necessarily reflect primitiveness. Cells in colonies derived from committed progenitors are usually large stellate-like cells, while in colonies derived from stem cells are often small and fusiform (Gothard et al., 2013). In this case, cell morphology may be a useful tool to tell apart exhausted or expanding small- and medium-sized colonies.

As discussed above, growth factor concentrations in FBS differs among serum lots, and does have significant outcomes on CFU-f size, frequency and even colony morphology. Viewed in terms of the Selective Growth Hypothesis (Figure 2), distinct categories of mesenchymal progenitors may be dependent upon different growth factors (and concentrations) to proliferate (or remain quiescent) in vitro.

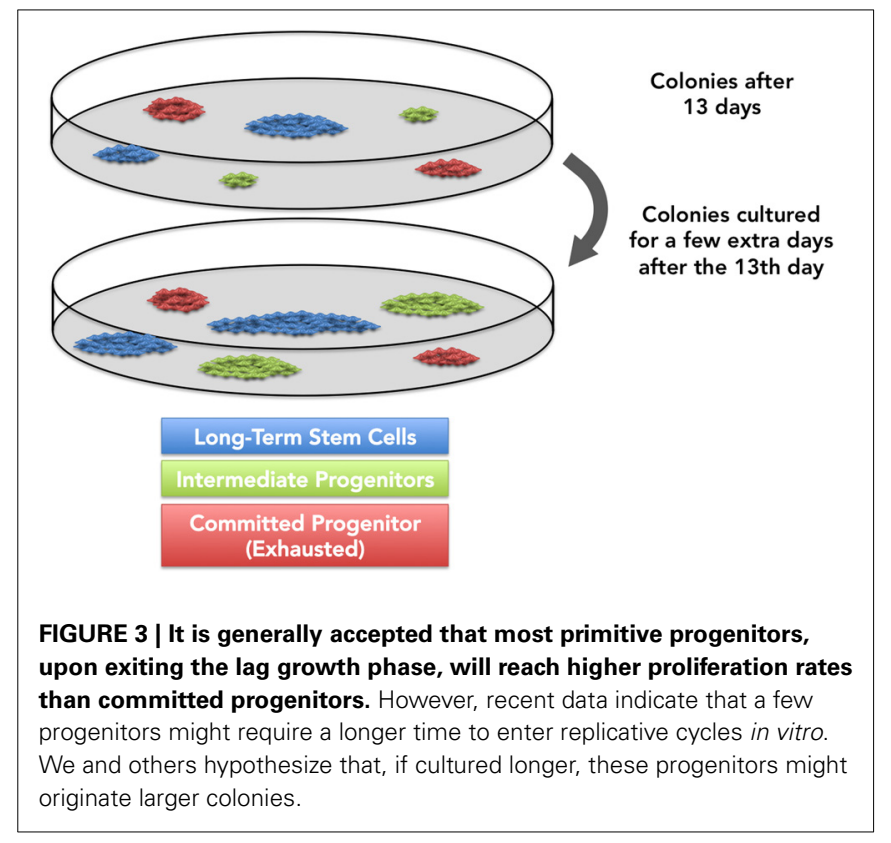

\section{PROGENITORS ADHESION IN VITRO}

Previously published data imply that all human bone marrowderived mesenchymal stem cells and progenitors with the ability to form fibroblast-like cell colonies adhere within $2-48 \mathrm{~h}$ in vitro, followed by a fetal bovine serum-dependent growth (Friedenstein, 1976; Castro-Malaspina et al., 1980; Kastrinaki et al., 2008; Kuznetsov et al., 2009). After this period of incubation, non-adherent cells are discarded and adherent cells are further expanded for at least 10 additional days. The original protocol designed by Friedenstein and coworkers, and corroborated by several other laboratories (Friedenstein et al., 1966, 1970; Owen and Friedenstein, 1988), established the requirement for a 72-h adhesion period prior to the elimination of non-adherent cells. This adhesion period is still considered a critical step for isolation and expansion of these progenitors. It has been described that bone marrow stromal cells must adhere to a substrate in vitro for their survival and proliferation, regardless their differentiation potential (Bruder et al., 1997; Pittenger et al., 1999; Dominici et al., 2006). Notwithstanding, authors demonstrate that stromal progenitor cells, or at least a subset of them, can be maintained in stirred suspension cultures for 21 days, and might even proliferate when induced by a combination of cytokines and growth factors (Baksh et al., 2003). Which specific stromal progenitors subsets remain in suspension are yet to be determined.

The average colony forming efficiency for normal human adult bone marrow may vary from 1 to 30 per $1 \times 10^{5}$ nucleated marrow cells (Beresford et al., 1994; Oreffo et al., 1998; Doucet et al., 2005; Bernardo et al., 2007; Kuznetsov et al., 2009). As previously discussed (Kuznetsov et al., 2009), such different values might be the result of either distinct cell isolation/preparation procedures or cell culture conditions, the latter meaning FBS capacity to induce progenitors proliferation in vitro. Although proliferation status has been a very useful tool to evaluate FBS quality, progenitors adhesion capacity, not usually considered, is crucial for colony forming efficiency and does affect the results. 
It is not clear, however, if and how different concentrations of growth factors and cytokines in FBS would impact progenitors adhesion in vitro. Most recently, Di Maggio and coworkers (Di Maggio et al., 2012) demonstrated that highly proliferative multipotent progenitors can be isolated from the non-adherent fraction, after 3 days, when bone marrow cells are cultured in the presence of FGF2. In addition to previous observations (Baksh et al., 2003), these data indicate that mesenchymal progenitors, or at least a subset, might change its adhesion properties accordingly as growth factors and cytokines concentration change in FBS. Currently, it is difficult to precise how much time mesenchymal stem cells and progenitors need to adhere in vitro, and how it is influenced by FBS growth factors concentrations. Further studies will be necessary as progenitors adhesion represents one crucial step when it comes to mesenchymal progenitors isolation.

\section{PERSPECTIVE}

The fibroblast-like colony-forming assay is simple to perform: cells are plated; progenitors adhere to the substrate and proliferate in a short culture period; cells are fixed and stained; colonies with more than 50 cells are counted. The number of progenitors in a given cell population can be easily approximated. Colony-forming efficiency results, however, depend upon an optimized procedure and several steps must be optimized to provide linear and reproducible data. Herein, our purpose was to revisit this classic method and open a discussion based on three issues to assist assay performance and data interpretation, but mostly to help researchers establish in their labs a standardized procedure. It is critical to optimize the ability of the cells to proliferate in response to growth factors present in the FBS, or any other source used, and this is commonly neglected due to the "quantification-only" use of the method. As a renewable source for tissue regeneration, in vitro cell expansion is almost always required for MSC populations, meaning that these cells will not be used as primary cultures, but only after, at least, 3 passages. It would be expected that after several rounds of expansion, most primitive progenitors and stem cells would take over the culture at the expense of other progenitors. Nevertheless, this has not been well elucidated so far and it is not known how mesenchymal population responds to different growth factors concentration in different serum lots. Although several research groups have described different strategies MSCs, the cell populations obtained and expanded remain heterogeneous in terms of stem cells and committed progenitors regardless of the method used for isolation (Muraglia et al., 2000; Sacchetti et al., 2007). No current method ensures isolation of a pure population of MSCs, or even whether this is desirable but this fact, the lack of standards, makes difficult understanding of the biology and true potential of these cells.

For these reasons it would be interesting that researchers establish a "surveillance system" when working with mesenchymal progenitors isolation and expansion. We therefore propose a list of three procedures recommended as controls. First, it would be highly desirable for each laboratory to keep a standard collection of bone marrow samples to be used as references for testing serum lots. Conceptually, each lab could select representative bone marrow samples, split each of them into equal aliquots (10, 20,30 , or as many as possible), freeze all at the same time, and cryopreserve (Figure 4). These aliquots will be used to test serum "quality" every time changes of lots are necessary.

As a second control instrument, the influence of FBS in progenitors adhesion should be evaluated, regarding colony forming efficiency (Figure 5). In one group (we suggest triplicate), bone marrow cells are incubated in culture medium supplemented with control serum. After $72 \mathrm{~h}$, non-adherent cells are discarded and adherent cells are cultured for 10 additional days also in culture medium supplemented with control FBS. In another group, bone marrow cells are incubated in culture medium supplemented with testing serum. After $72 \mathrm{~h}$, non-adherent cells are discarded and adherent cells are culture for 10 additional days in culture medium supplemented with control FBS. The main objective of the assay is to analyze if different serum lots contribute to colony forming efficiency change at the expense of cell adhesion or cell proliferation.

Mesenchymal progenitors' self-renewal capacity can be tested by evaluating the ability of expanded clones to originate secondary colonies upon replating. As a third parameter, we propose the secondary colony forming efficiency assay (Figure 6). One thousand cells from the primary colony-forming cultures may be replated and cultured for additional 10 days. Cells are, then, fixed and stained. It is important to highlight that, in all three assays colony numbers, and colony size must be rigorously evaluated and compared.

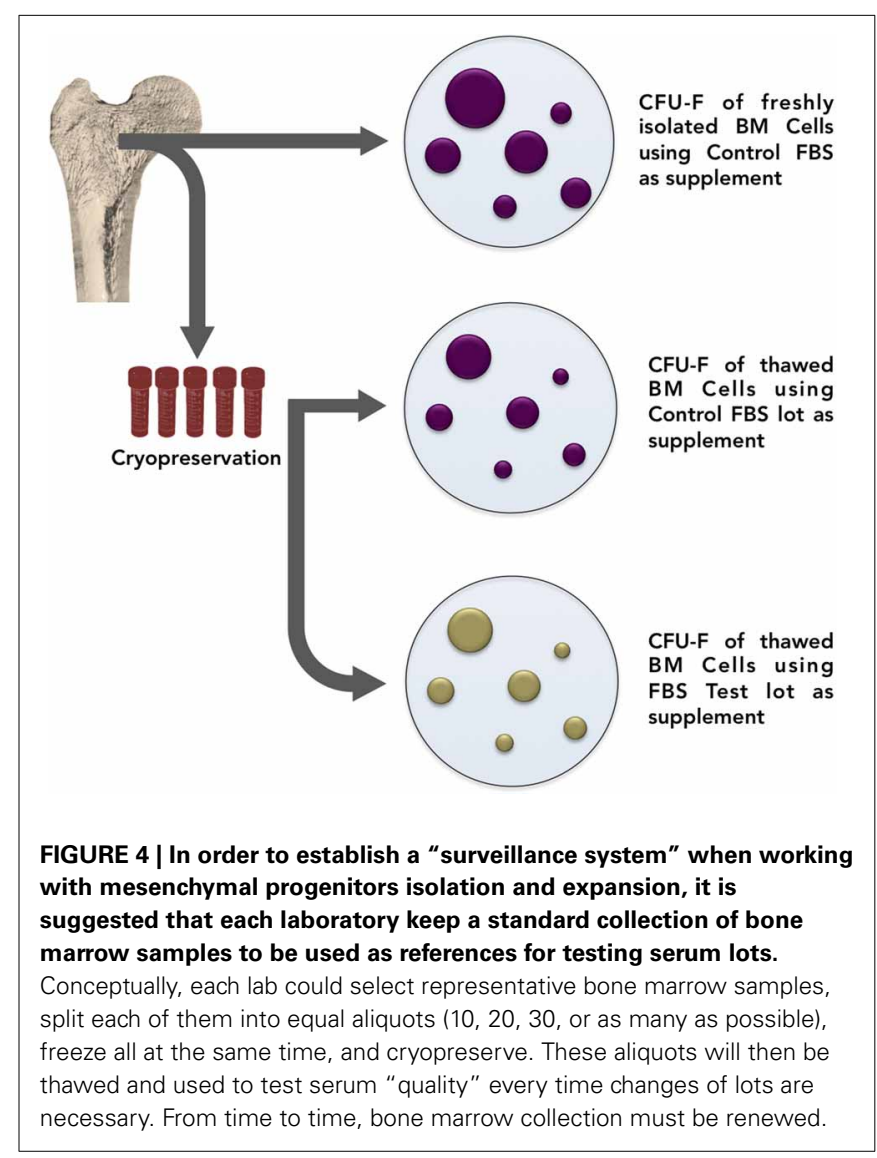



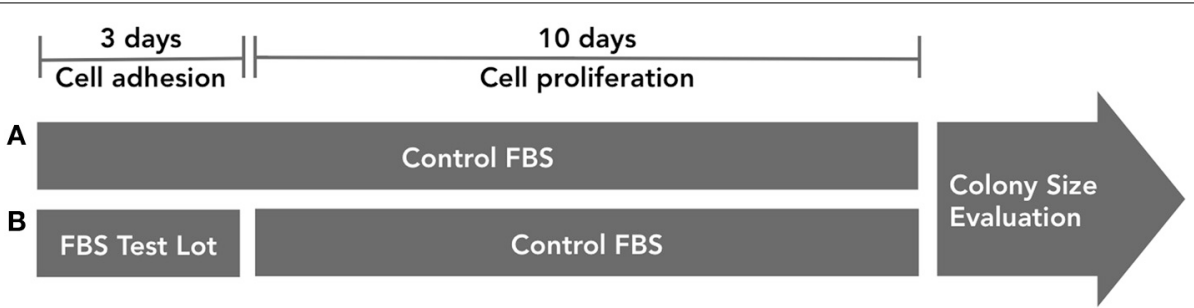

FIGURE 5 | FBS influence on progenitor cell adhesion in vitro must be tested. In group (A), bone marrow cells are incubated in culture medium supplemented with control serum. After $72 \mathrm{~h}$, non-adherent cells are discarded and adherent cells are cultured for 10 additional days also in culture medium supplemented with control FBS. In group
(B), bone marrow cells are incubated in culture medium supplemented with testing serum. After $72 \mathrm{~h}$, non-adherent cells are discarded and adherent cells are culture for 10 additional days in culture medium supplemented with control FBS. Colony numbers and size must be evaluated.

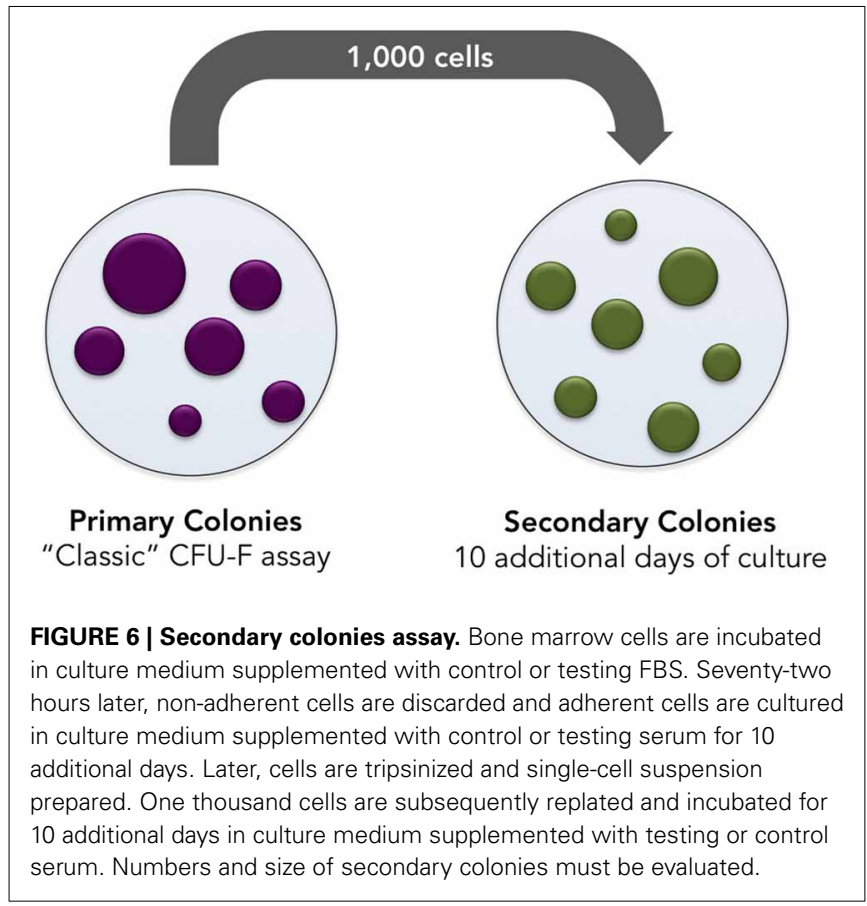

It is clear that cell behavior in vivo and in vitro changes from person to person, from animal to animal, even among syngeneic siblings, and over time in the same individual. We propose that these three strategies combining in-colony proliferation rate analyses with colonies formation and quantification, progenitors adhesion, and recloning ability, if used as a lab surveillance instrument, will assist in the development of a greater understanding of the biology of MSCs and other adherent populations in vitro. We would like to propose the creation of control guidelines which will facilitate the identification and isolation of long-term stem cells and short-term progenitors as a crucial step to better explore their potential and define their applicability in the cell therapy and bioengineering fields.

\section{ACKNOWLEDGMENTS}

We must thank Professor Radovan Borojevic and Professor Adriana Cesar Bonomo for their enthusiastic and provocative discussions, and support which inspired this perspective.
This work was directly supported by Ministry of Science and Technology (MCT) through the Brazilian National Council for Scientific and Technological Development - CNPq, and Carlos Chagas Filho Foundation for Research Support in Rio de Janeiro - FAPERJ; by grants from the DOD (W81XWH-11-10684) PC100829 CA093900 and the National Institute of Health (AR0568903, R44 DE022493-02A10, DE022493, DK082481). This work is also supported, in part, by the Intramural Program of the National Institute on Aging, NIH. PC100829 CA093900 1U54CA163124-01.

\section{REFERENCES}

Andreeva, E. R., Pugach, I. M., Gordon, D., and Orekhov, A. N. (1998). Continuous subendothelial network formed by pericyte-like cells in human vascular bed. Tissue Cell 30, 127-135. doi: 10.1016/S0040-8166(98)80014-1

Baksh, D., Davies, J. E., and Zandstra, P. W. (2003). Adult human bone marrowderived mesenchymal progenitor cells are capable of adhesion-independent survival and expansion. Exp. Hematol. 31, 723-732. doi: 10.1016/S0301472X(03)00106-1

Barry, F., Boynton, R., Murphy, M., Haynesworth, S., and Zaia, J. (2001). The SH-3 and SH-4 antibodies recognize distinct epitopes on CD73 from human mesenchymal stem cells. Biochem. Biophys. Res. Commun. 289, 519-724. doi: 10.1006/bbrc.2001.6013

Barry, F. P., Boynton, R. E., Haynesworth, S., Murphy, J. M., and Zaia, J. (1999). The monoclonal antibody SH-2, raised against human mesenchymal stem cells, recognizes an epitope on endoglin (CD105). Biochem. Biophys. Res. Commun. 265, 134-139. doi: 10.1006/bbrc. 1999.1620

Beresford, J. N., Joyner, C. J., Devlin, C., and Triffitt, J. T. (1994). The effects of dexamethasone and 1,25-dihydroxyvitamin D3 on osteogenic differentiation of human marrow stromal cells in vitro. Arch. Oral Biol. 39, 941-947. doi: 10.1016/0003-9969(94)90077-9

Bernardo, M. E., Avanzini, M. A., Perotti, C., Cometa, A. M., Moretta, A., Lenta, E., et al. (2007). Optimization of in vitro expansion of human multipotent mesenchymal stromal cells for cell-therapy approaches: further insights in the search for a fetal calf serum substitute. J. Cell. Physiol. 211, 121-130. doi: $10.1002 /$ icp. 20911

Bianco, P. (2011). Minireview: the stem cell next door: skeletal and hematopoietic stem cell "niches" in bone. Endocrinology 152, 2957-2962. doi: 10.1210/en. 2011-0217

Bianco, P., Cao, X., Frenette, P. S., Mao, J. J., Robey, P. G., Simmons, P. J., et al. (2013). The meaning, the sense and the significance: translating the science of mesenchymal stem cells into medicine. Nat. Med. 19, 35-42. doi: 10.1038/nm.3028

Bianco, P., Costantini, M., Dearden, L. C., and Bonucci, E. (1988). Alkaline phosphatase positive precursors of adipocytes in the human bone marrow. Br. J. Haematol. 68, 401-403. doi: 10.1111/j.1365-2141.1988.tb04225.x

Bruder, S. P., Jaiswal, N., and Haynesworth, S. E. (1997). Growth kinetics, selfrenewal, and the osteogenic potential of purified human mesenchymal stem cells during extensive subcultivation and following cryopreservation. J. Cell. 
Biochem. 64, 278-294. doi: 10.1002/(SICI)1097-4644(199702)64:2<278::AIDJCB11>3.0.CO;2-F

Caplan, A. I. (1991). Mesenchymal stem cells. J. Orthop. Res. 9, 641-650. doi: 10.1002/jor.1100090504

Caplan, A. I. (2007). Adult mesenchymal stem cells for tissue engineering versus regenerative medicine. J. Cell. Physiol. 213, 341-347. doi: 10.1002/jcp.21200

Carow, C. E., Hangoc, G., and Broxmeyer, H. E. (1993). Human multipotential progenitor cells (CFU-GEMM) have extensive replating capacity for secondary CFU-GEMM: an effect enhanced by cord blood plasma. Blood 81, 942-949.

Castro-Malaspina, H., Gay, R. E., Resnick, G., Kapoor, N., Meyers, P., Chiarieri, D., et al. (1980). Characterization of human bone marrow fibroblast colonyforming cells (CFU-F) and their progeny. Blood 56, 289-301.

Corselli, M., Chen, C.-W., Sun, B., Yap, S., Rubin, J. P., and Péault, B. (2011). The tunica adventitia of human arteries and veins as a source of mesenchymal stem cells. Stem Cells Dev. 21, 1299-1308. doi: 10.1089/scd.2011.0200

Crisan, M., Chen, C.-W., Corselli, M., Andriolo, G., Lazzari, L., and Péault, B. (2009). Perivascular multipotent progenitor cells in human organs. Ann. N. Y. Acad. Sci. 1176, 118-123. doi: 10.1111/j.1749-6632.2009.04967.x

Crisan, M., Huard, J., Zheng, B., Sun, B., Yap, S., Logar, A., et al. (2008a). Purification and culture of human blood vessel-associated progenitor cells. Curr. Protoc. Stem Cell Biol. 86, 295-309. doi: 10.1002/9780470151808. sc02b02s4

Crisan, M., Yap, S., Casteilla, L., Chen, C.-W., Corselli, M., Park, T. S., et al. (2008b). A perivascular origin for mesenchymal stem cells in multiple human organs. Cell Stem Cell 3, 301-313. doi: 10.1016/j.stem.2008.07.003

Da Silva Meirelles, L., Chagastelles, P. C., and Nardi, N. B. (2006). Mesenchymal stem cells reside in virtually all post-natal organs and tissues. J. Cell Sci. 119, 2204-2213. doi: 10.1242/jcs.02932

Dennis, J. E., Carbillet, J.-P., Caplan, A. I., and Charbord, P. (2002). The STRO-1+ marrow cell population is multipotential. Cells Tissues Organs 170, 73-82. doi: 10.1159/000046182

Dexter, T. M. (1979). Cell interactions in vitro. Clin. Haematol. 8, 453-468.

Di Maggio, N., Mehrkens, A., Papadimitropoulos, A., Schaeren, S., Heberer, M., Banfi, A., et al. (2012). FGF-2 Maintains a niche-dependent population of self-renewing highly potent non-adherent mesenchymal progenitors through FGFR2c. Stem Cells 30, 1455-1464. doi: 10.1002/stem.1106

Dominici, M., Le Blanc, K., Mueller, I., Slaper-Cortenbach, I., Marini, F., Krause, D., et al. (2006). Minimal criteria for defining multipotent mesenchymal stromal cells. the international society for cellular therapy position statement. Cytotherapy 8, 315-317. doi: 10.1080/14653240600855905

Doucet, C., Ernou, I., Zhang, Y., Llense, J.-R., Begot, L., Holy, X., et al. (2005). Platelet lysates promote mesenchymal stem cell expansion: a safety substitute for animal serum in cell-based therapy applications. J. Cell. Physiol. 205, 228-236. doi: $10.1002 /$ jcp. 20391

Friedenstein, A. J. (1976). Precursor cells of mechanocytes. Int. Rev. Cytol. 47, 327-359. doi: 10.1016/S0074-7696(08)60092-3

Friedenstein, A. J., Chailakhjan, R. K., and Lalykina, K. S. (1970). The development of fibroblast colonies in monolayer cultures of guinea-pig bone marrow and spleen cells. Cell Tissue Kinet. 3, 393-403.

Friedenstein, A. J., Chailakhyan, R. K., Latsinik, N. V., Panasyuk, A. F., and Keiliss-Borok, I. V. (1974a). Stromal cells responsible for transferring the microenvironment of the hemopoietic tissues. Cloning in vitro and retransplantation in vivo. Transplantation 17, 331-340. doi: 10.1097/00007890-19740400000001

Friedenstein, A. J., Deriglasova, U. F., Kulagina, N. N., Panasuk, A. F., Rudakowa, S. F., Luriá, E. A., et al. (1974b). Precursors for fibroblasts in different populations of hematopoietic cells as detected by the in vitro colony assay method. Exp. Hematol. 2, 83-92.

Friedenstein, A. J., Latzinik, N. W., Grosheva, A. G., and Gorskaya, U. F. (1982). Marrow microenvironment transfer by heterotopic transplantation of freshly isolated and cultured cells in porous sponges. Exp. Hematol. 10, 217-227.

Friedenstein, A. J., Piatetzky-Shapiro, I. I., and Petrakova, K. V. (1966). Osteogenesis in transplants of bone marrow cells. J. Embryol. Exp. Morphol. 16, 381-390.

Gazit, R., Weissman, I. L., and Rossi, D. J. (2008). Hematopoietic stem cells and the aging hematopoietic system. Semin. Hematol. 45, 218-224. doi: 10.1053/j.seminhematol.2008.07.010

Gothard, D., Dawson, J. I., and Oreffo, R. O. C. (2013). Assessing the potential of colony morphology for dissecting the CFU-F population from human bone marrow stromal cells. Cell Tissue Res. 352, 237-247. doi: 10.1007/s00441-0131564-3

Hao, Q. L., Thiemann, F. T., Petersen, D., Smogorzewska, E. M., and Crooks, G. M. (1996). Extended long-term culture reveals a highly quiescent and primitive human hematopoietic progenitor population. Blood 88, 3306-3313.

Horwitz, E. M., Le Blanc, K., Dominici, M., Mueller, I., Slaper-Cortenbach, I., Marini, F. C., et al. (2005). Clarification of the nomenclature for MSC: The international society for cellular therapy position statement. Cytotherapy 7, 393-395. doi: 10.1080/14653240500319234

Jones, E. A., Kinsey, S. E., English, A., Jones, R. A., Straszynski, L., Meredith, D. M., et al. (2002). Isolation and characterization of bone marrow multipotential mesenchymal progenitor cells. Arthritis Rheum. 46, 3349-3360. doi: 10.1002/art.10696

Kastrinaki, M.-C., Andreakou, I., Charbord, P., and Papadaki, H. A. (2008). Isolation of human bone marrow mesenchymal stem cells using different membrane markers: comparison of colony/cloning efficiency, differentiation potential, and molecular profile. Tissue Eng. Part C. Methods 14, 333-339. doi: 10.1089/ten.tec.2008.0173

Kuznetsov, S. A., Mankani, M. H., Bianco, P., and Robey, P. G. (2009). Enumeration of the colony-forming units-fibroblast from mouse and human bone marrow in normal and pathological conditions. Stem Cell Res. 2, 83-94. doi: 10.1016/j.scr.2008.07.007

Latsinik, N. V., and Epikhina, S. Y. (1974). Adhesive properties of hematopoietic and lymphoid cells forming fibroblast colonies in monolayer cultures. Bull. Exp. Biol. Med. 76, 1459-1461. doi: 10.1007/BF00787562

Maier, C. L., Shepherd, B. R., Yi, T., and Pober, J. S. (2010). Explant outgrowth, propagation and characterization of human pericytes. Microcirculation 17, 367-380. doi: 10.1111/j.1549-8719.2010.00038.x

Mannello, F., and Tonti, G. A. (2007). Concise review: no breakthroughs for human mesenchymal and embryonic stem cell culture: conditioned medium, feeder layer, or feeder-free; medium with fetal calf serum, human serum, or enriched plasma; serum-free, serum replacement nonconditioned medium, o. Stem Cells 25, 1603-1609. doi: 10.1634/stemcells.2007-0127

Morrison, S. J., Uchida, N., and Weissman, I. L. (1995). The biology of hematopoietic stem cells. Annu. Rev. Cell Dev. Biol. 11, 35-71. doi: 10.1146/annurev.cb.11.110195.000343

Muraglia, A., Cancedda, R., and Quarto, R. (2000). Clonal mesenchymal progenitors from human bone marrow differentiate in vitro according to a hierarchical model. J. Cell Sci. 113(Pt 7), 1161-1166.

Nicola, N. A., and Metcalf, D. (1986). Specificity of action of colony-stimulating factors in the differentiation of granulocytes and macrophages. Ciba Found. Symp. 118, 7-28.

Oh, I.-H., and Humphries, R. K. (2012). Concise review: multidimensional regulation of the hematopoietic stem cell state. Stem Cells 30, 82-88. doi: $10.1002 /$ stem.776

Oreffo, R. O., Bord, S., and Triffitt, J. T. (1998). Skeletal progenitor cells and ageing human populations. Clin. Sci. (Lond). 94, 549-555.

Owen, M., and Friedenstein, A. J. (1988). Stromal stem cells: marrow-derived osteogenic precursors. Ciba Found. Symp. 136, 42-60.

Péault, B. (2012). Are mural cells guardians of stemness?: from plurito multipotency via vascular pericytes. Circulation 125, 12-13. doi: 10.1161/CIRCULATIONAHA.111.073445

Petzer, A. L., Hogge, D. E., Landsdorp, P. M., Reid, D. S., and Eaves, C. J. (1996). Self-renewal of primitive human hematopoietic cells (long-termculture-initiating cells) in vitro and their expansion in defined medium. Proc. Natl. Acad. Sci. U.S.A. 93, 1470-1474. doi: 10.1073/pnas.93.4.1470

Pittenger, M. F., Mackay, A. M., Beck, S. C., Jaiswal, R. K., Douglas, R., Mosca, J. D., et al. (1999). Multilineage potential of adult human mesenchymal stem cells. Science 284, 143-147. doi: 10.1126/science.284.5411.143

Ponchio, L., Conneally, E., and Eaves, C. (1995). Quantitation of the quiescent fraction of long-term culture-initiating cells in normal human blood and marrow and the kinetics of their growth factor-stimulated entry into S-phase in vitro. Blood 86, 3314-3321.

Queensberry, P. J., Bealmear, P., Ryan, M., and Stohlman, F. (1974). Serum colony stimulating and inhibiting factors in irradiated germfree and conventional mice. Br. J. Haematol. 28, 531-539. doi: 10.1111/j.1365-2141.1974.tb06672.x

Quesenberry, P. J., McNiece, I. K., Robinson, B. E., Woodward, T. A., Baber, G. B., McGrath, H. E., et al. (1987). Stromal cell regulation of lymphoid and myeloid differentiation. Blood Cells 13, 137-146. 
Russell, K. C., Phinney, D. G., Lacey, M. R., Barrilleaux, B. L., Meyertholen, K. E., and O'Connor, K. C. (2010). In vitro high-capacity assay to quantify the clonal heterogeneity in trilineage potential of mesenchymal stem cells reveals a complex hierarchy of lineage commitment. Stem Cells 28, 788-798. doi: 10.1002/stem.312

Sacchetti, B., Funari, A., Michienzi, S., Di Cesare, S., Piersanti, S., Saggio, I., et al. (2007). Self-renewing osteoprogenitors in bone marrow sinusoids can organize a hematopoietic microenvironment. Cell 131, 324-336. doi: 10.1016/j.cell.2007.08.025

Sarugaser, R., Hanoun, L., Keating, A., Stanford, W. L., and Davies, J. E. (2009). Human mesenchymal stem cells self-renew and differentiate according to a deterministic hierarchy. PLoS ONE 4:e6498. doi: 10.1371/journal.pone.0006498

Satomura, K., Krebsbach, P., Bianco, P., and Gehron Robey, P. (2000). Osteogenic imprinting upstream of marrow stromal cell differentiation. J. Cell. Biochem. 78, 391-403. doi: 10.1002/1097-4644(20000901)78:3\%3C391::AIDJCB5\%3E3.0.CO;2-E

Shi, S., and Gronthos, S. (2003). Perivascular niche of postnatal mesenchymal stem cells in human bone marrow and dental pulp. J. Bone Miner. Res. 18, 696-704. doi: 10.1359/jbmr.2003.18.4.696

Shih, I. M. (1999). The role of CD146 (Mel-CAM) in biology and pathology. J. Pathol. 189, 4-11. doi: 10.1002/(SICI)1096-9896(199909)189:1<4::AIDPATH332>3.0.CO;2-P

Stanley, E. R., Bradley, T. R., and Sumner, M. A. (1971). Properties of the mouse embryo conditioned medium factor(s) stimulationg colony formation by mouse bone marrow cells grown in vitro. J. Cell. Physiol. 78, 301-317. doi: 10.1002/jcp.1040780219

Taichman, R. S., Wang, Z., Shiozawa, Y., Jung, Y., Song, J., Balduino, A., et al. (2010). Prospective identification and skeletal localization of cells capable of multilineage differentiation in vivo. Stem Cells Dev. 19, 1557-1570. doi: 10.1089/scd. 2009.0445

Tuli, R., Tuli, S., Nandi, S., Wang, M. L., Alexander, P. G., Haleem-Smith, H., et al. (2003). Characterization of multipotential mesenchymal progenitor cells derived from human trabecular bone. Stem Cells 21, 681-693. doi: 10.1634/stemcells.21-6-681

Urabe, A., Murphy, M. J., Haghbin, M., and Gee, T. S. (1979). Erythroid progenitors (BFU-e and CFU-e) in acute leukaemia. J. Clin. Pathol. 32, 666-669. doi: 10.1136/jcp.32.7.666

Wagner, J., Kean, T., Young, R., Dennis, J. E., and Caplan, A. I. (2009). Optimizing mesenchymal stem cell-based therapeutics. Curr. Opin. Biotechnol. 20, 531-536. doi: 10.1016/j.copbio.2009.08.009

Zannettino, A. C. W., Harrison, K., Joyner, C. J., Triffitt, J. T., and Simmons, P. J. (2003). Molecular cloning of the cell surface antigen identified by the osteoprogenitor-specific monoclonal antibody, HOP-26. J. Cell. Biochem. 89, 56-66. doi: $10.1002 / j \mathrm{cb} .10481$

Conflict of Interest Statement: The authors declare that the research was conducted in the absence of any commercial or financial relationships that could be construed as a potential conflict of interest.

Received: 30 October 2013; paper pending published: 28 November 2013; accepted: 24 February 2014; published online: 27 March 2014.

Citation: Cordeiro-Spinetti E, de Mello W, Trindade LS, Taub DD, Taichman RS and Balduino A. (2014) Human bone marrow mesenchymal progenitors: perspectives on an optimized in vitro manipulation. Front. Cell Dev. Biol. 2:7. doi: 10.3389/fcell. 2014.00007

This article was submitted to Stem Cell Research, a section of the journal Frontiers in Cell and Developmental Biology.

Copyright (C) 2014 Cordeiro-Spinetti, de Mello, Trindade, Taub, Taichman and Balduino. This is an open-access article distributed under the terms of the Creative Commons Attribution License (CC BY). The use, distribution or reproduction in other forums is permitted, provided the original author(s) or licensor are credited and that the original publication in this journal is cited, in accordance with accepted academic practice. No use, distribution or reproduction is permitted which does not comply with these terms. 